\title{
Cross Border Shopping from the Perspective of Domestic Tourists in Padang Besar, Perlis
}

\author{
Azila Azmi \\ Nurdin Ibrahim \\ Aida Khalida Mohamed Idris \\ Zamri Ahmad \\ Norfezah Md Nor \\ Universiti Teknlogi MARA Pulau Pinang, Malaysia
}

\begin{abstract}
Padang Besar is a border town in Malaysia and it is located in the northern part of Perlis, which shares a border with the province of Songkhla, Thailand. This border town is popular for shopping activities among Malaysian and Thai. Most visitors and tourists come during the weekends, sometimes up to thousands at one time. This research paper examines the motivations of cross border shoppers from the perspective of domestic tourists in Padang Besar, Perlis. The objective is to identify the consumer characteristics and analyze the relationship between market characteristics with cross border shopping. This study employs quantitative method and the data were collected using self-administered questionnaires. Statistical software was used to analyze the 375 returned questionnaires. The findings revealed that most of the domestic tourists came from the lower income group and most of them were day tripper. They tend to spend more on food and beverages, while their average spending is more than RM300. Moreover, market characteristics show strong positive relationship towards this shopping activity. The information gathered is beneficial for both neighbouring countries as the government can help to improve the shopping area by facilitating the development with related tourism infrastructure and amenities.
\end{abstract}

Keywords: shopping tourism, border town, consumer characteristics, market characteristics

\section{Introduction}

Tourism is known as a social, cultural and economic phenomenon that involves a visitor's movement to destinations. The visitor travels from one destination to another for leisure or business purposes. Trippers may experience different environment while they are away from home. Meanwhile, tourists have intention to return home after visit and they stay for short term periods at the destinations ${ }^{[1]}$. In addition, many tourists visit Thailand on business leisure, or shopping trips. Padang Besar, Perlis, is a border town that lies between north Malaysia and south Thailand, and is famous for border shopping activities since the early 1950s. Padang Besar offers a huge market which houses varieties of items for sale and it is known as Padang Besar Business Arcade Complex or PBAC. Previous study indicates that the main attraction of tourism activities in Padang Besar is centered at PBAC as it hosts most shopping activities. Based on observations in Padang Besar, most visitors tend to shop at PBAC than the other shopping venues ${ }^{[2,6]}$. Observation also reveals that most visitors were domestic tourists. Domestic tourists in this study are Malaysian visiting Padang Besar or specifically, those tourists travelling within a country and do not need passport or visa.

To date, there are few studies conducted in Malaysia based on the cross border shopping activities such as the study on behaviour of Bruneian in Limbang, Sarawak ${ }^{[2]}$ and Singaporean outshopping activities in Johor ${ }^{[14]}$. Thus, only a number of 
studies were conducted on cross border shopping pattern in the borderland in between Malaysia and Thailand. Previous researches on Padang Besar were focusing on shopping development and trading activities ${ }^{[6,7]}$. Hence, this study is conducted to fill in the gap on cross border shopping activities of domestic tourists specifically those in Padang Besar, focusing on the consumer characteristics and market characteristics. Consumer characteristics are often used to predict how likely a group of people to purchase a product, while market characteristics are referring to cheaper price, variety of goods, lower tax, accessibility, communication, social status and opening hours ${ }^{[4]}$ that attracts visitors to cross border shopping destination. Herein study, consumer characteristics are discussed based on the demographic profile, travel pattern, and spending pattern of the respondents in Padang Besar.

In line with the above notion, this study seeks to answer the following research questions:

1. What are the consumer characteristics in Padang Besar?

2. What is the relationship between market characteristics with cross border shopping activities?

\section{Malaysia Cross Border Shopping}

Malaysia is located in the heart of Southeast Asia and neighboring with nations like Thailand, Singapore, Indonesia, and Brunei. Most of the border towns between Malaysia and Thailand are famous with shopping activities due to duty free areas. Malaysians cross the border to enjoy the tasty Thai food in Thai restaurants or stalls and also a lot of choices for shopping, meanwhile Thai tourists come to Malaysia to buy unique products. The duty free items offered to guests are clothing, cigarettes, alcohols, chocolates, cameras, beauty products, souvenirs, and others ${ }^{[5,6,7]}$.

Furthermore, the main factor that influenced the border movement between Malaysia and Singapore is the availability of the transportation links between the countries such as trains, buses, taxis, and cars ${ }^{[8]}$. For Malaysia and Indonesia, the border town is located at Serikin, Sarawak. Ever since long time ago, individuals from both sides have relations and social association, thus enabling people from both nations enjoyed shopping in the border areas in Serikin, Sarawak ${ }^{[9]}$. They like to shop due to such remunerations as affordable price which they can bargain price and variety of goods to be chosen from.

Apart from that, another border town in Malaysia that is known for cross-border activities is located between Malaysia and Brunei. Malaysian and Bruneian cross the border for tourism activities. Most Bruneian cross the border to Limbang to buy groceries. The factors that determined Bruneian to cross the border to Limbang, Sarawak, is a result of the higher

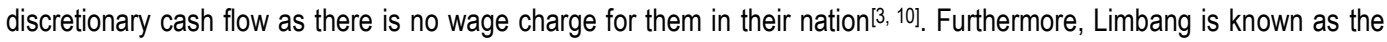
center for people to run illegal activities like prostitution. This activity attracts more Bruneian to visit Limbang and encourages them to fulfill their desire.

\section{Research Methodology}

In this research, the researcher used simple random sampling in choosing the sample of respondents. The samples of the subject matter involving the domestic tourists who came from every state in Malaysia and having their own reasons to come to Padang Besar. It is mentioned that populations are characterized as individuals, people, associations, gatherings or groups that the researchers hope to answer the questionnaires ${ }^{[11]}$.

This research focused on local tourists who travel to North Malaysia especially to Padang Besar, Perlis, which is famous of its shopping areas. The researcher received 375 valid responses out of 400 self-administrative questionnaires distributed in the border town of Padang Besar. The respondents were randomly selected while they were shopping at major shopping arcade in Padang Besar. The instrument design for this study was adapted from prominent researchers ${ }^{[12,13]}$.

\section{Result and Discussion}


From the simple random sampling method, the result was obtained and 375 questionnaires were analyzed. For the demographic profiles, it showed that male tourists make up $48.8 \%$ and $51.2 \%$ female. Previous study mentioned that most Singaporean traveled to another country for shopping reason and spent on clothes, handbags, shoes, cosmetics, and household items $\left.{ }^{14}\right]$. It shows that cross border shopping can undoubtedly attract female shoppers because of the specialty of the items which are offered to them. Most of the respondents are aged between $18-24$ years old.

Majority of the tourists answered that they are single in terms of their marital status. $75.7 \%$ of the respondents have certificate/diploma/degree for their education background level. With two highest ranked, $44.5 \%$ are students and $36.5 \%$ are employed respondents which showed that these two groups always come to the researched area. Employment category (others) showed half percentage value (51. 5\%) as compared to other categories. Students and housewives are included in the other employment categories based on the survey. Most of the respondents were in the lower income group which was less than RM3000 per month while most of the respondents' household income was less than RM5000.

\section{Table 1: Demographic Profile of Domestic Tourist}

\begin{tabular}{|c|c|c|c|}
\hline Variable & Response & Frequency & Percentage \\
\hline \multirow[t]{2}{*}{ Gender } & Male & 183 & 48.8 \\
\hline & Female & 192 & 51.2 \\
\hline \multirow[t]{7}{*}{ Age } & $18-24$ & 170 & 45.3 \\
\hline & $25-29$ & 98 & 26.1 \\
\hline & $30-34$ & 49 & 13.1 \\
\hline & $35-39$ & 29 & 7.7 \\
\hline & $40-44$ & 12 & 3.2 \\
\hline & $45-49$ & 4 & 1.1 \\
\hline & 50 and above & 13 & 3.5 \\
\hline \multirow[t]{3}{*}{ Marital Status } & Single & 251 & 66.9 \\
\hline & Married & 94 & 25.1 \\
\hline & Others & 30 & 8.0 \\
\hline \multirow[t]{5}{*}{ Education Level } & Primary & 7 & 1.9 \\
\hline & Secondary & 57 & 15.2 \\
\hline & Certificate/Diploma/ & 284 & 75.7 \\
\hline & Degree & 27 & 7.2 \\
\hline & Others & & \\
\hline \multirow[t]{6}{*}{ Occupation } & Student & 167 & 44.5 \\
\hline & Employed & 137 & 36.5 \\
\hline & Housewife & 28 & 7.5 \\
\hline & Unemployed & 16 & 4. 3 \\
\hline & Retired & 10 & 2.7 \\
\hline & Others & 17 & 4.5 \\
\hline \multirow{8}{*}{$\begin{array}{l}\text { Employment } \\
\text { Status }\end{array}$} & Professional and & 46 & 12. 3 \\
\hline & Managerial & 27 & 7.2 \\
\hline & Technical/Superviso & 38 & 10. 1 \\
\hline & ry & 19 & 5.1 \\
\hline & Clerical & 52 & 13.9 \\
\hline & Production/Operativ & 193 & 51.5 \\
\hline & $\begin{array}{l}\text { es } \\
\text { Self-employed }\end{array}$ & & \\
\hline & Others & & \\
\hline \multirow[t]{2}{*}{ Personal Income } & Less than $\$ 3000$ & 298 & 79.5 \\
\hline & $\$ 3000-\$ 5000$ & 66 & 17.6 \\
\hline
\end{tabular}




\begin{tabular}{llll}
\hline & $\$ 5000$ and above & 11 & 2.9 \\
Household & Less than $\$ 5000$ & 314 & 83.7 \\
Income & $\$ 5000-\$ 10000$ & 48 & 12.8 \\
& $\$ 10000$ and above & 13 & 3.5 \\
\hline
\end{tabular}

Table 2: Travel Pattern

\begin{tabular}{lll}
\hline Items & Frequency & Percentage \\
\hline Day tripper & & \\
Yes & 264 & 70.4 \\
No & 111 & 29.6
\end{tabular}

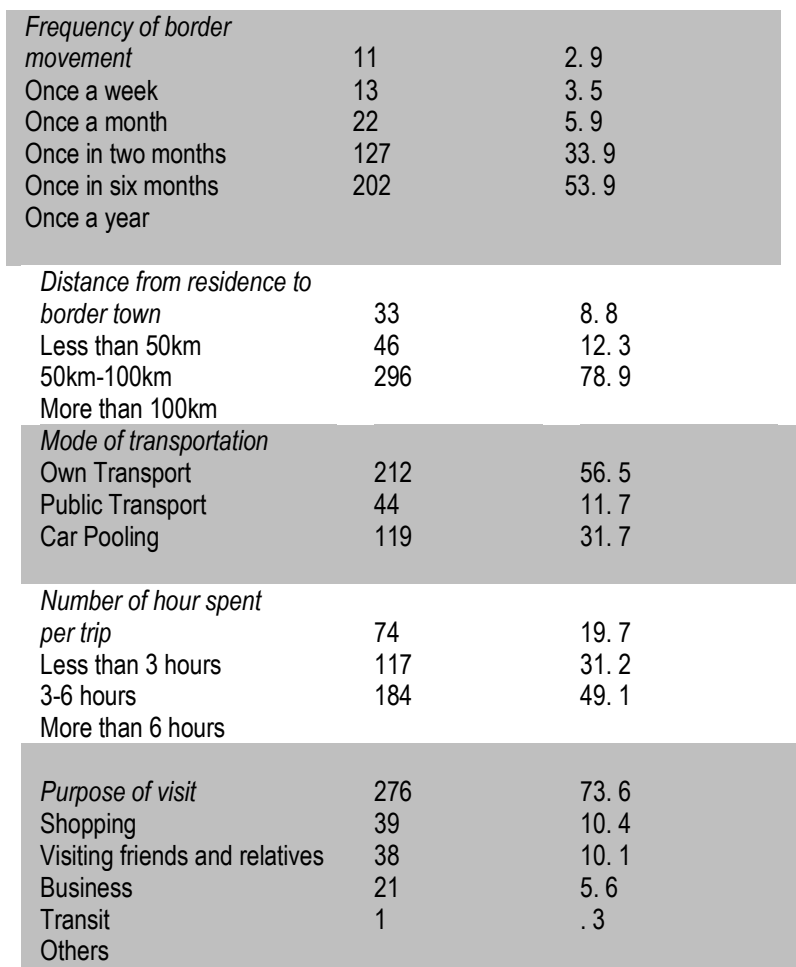

For the travel pattern, most of the domestic tourists basically were day trippers, who make the trips to Padang Besar, Perlis. From the survey, about $53.4 \%$ of the respondents cross the border at least once a year. The percentage of samples that resides more than $100 \mathrm{~km}$ from border town was $78.9 \%$, while $49.1 \%$ would spend their time more than 6 hours in Padang Besar (). The respondents using public transport has the least percentage (11.7\%). Although the availability of high-speed train of KTM, Electric Train Service (ETS) has routes from Kuala Lumpur, Ipoh, and Butterworth to Padang Besar, the tourists tend to use their own transport.

Shopping is the main purpose for domestic tourists to visit Padang Besar. As noted by many researchers, every author

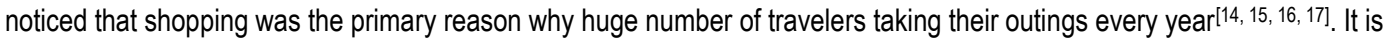
also a stated that $51 \%$ of the travel study mentioned that the main purpose in having trips in the past year is for shopping activity [1]. In fact, similar results were discovered, which evaluated that $47 \%$ of all those shopping trips taken by visitors asserting shopping as their essential or optional purpose for travel $[18,19]$ 
Table 3: Spending Pattern

\begin{tabular}{|c|c|c|}
\hline Items & Frequency & Percentage \\
\hline \multicolumn{3}{|c|}{ Food and beverages $(N=362)$} \\
\hline Less than RM50 & 198 & 54.7 \\
\hline RM51-Rm100 & 124 & 34.3 \\
\hline More than RM100 & 40 & 11.0 \\
\hline Clothes $(N=359)$ & 127 & 35.4 \\
\hline Less than RM100 & 151 & 42.1 \\
\hline RM101-RM150 & 81 & 22.6 \\
\hline More than RM150 & & \\
\hline
\end{tabular}

$\begin{array}{lll}\text { Shoes / handbags }(N=256) & 121 & 47.3 \\ \text { Less than RM100 } & 62 & 24.2 \\ \text { RM101-RM150 } & 73 & 28.5\end{array}$

\begin{tabular}{|c|c|c|}
\hline Household items $(N=62)$ & 41 & 66.1 \\
\hline Less than RM100 & 12 & 19. 4 \\
\hline $\begin{array}{l}\text { RM101-RM150 } \\
\text { More than RM150 }\end{array}$ & 9 & 14.5 \\
\hline
\end{tabular}

$\begin{array}{lll}\text { Cosmetics and beauty products }(\mathrm{N}=109) & 66 & 60.6 \\ \text { Less than RM100 } & 17 & 15.6 \\ \text { RM101-RM150 } & 26 & 23.9 \\ \text { More than RM150 } & & \end{array}$

\begin{tabular}{|c|c|c|}
\hline Toys $(N=41)$ & 35 & 85.4 \\
\hline Less than RM100 & 3 & 7.3 \\
\hline RM101-RM150 & 3 & 7.3 \\
\hline
\end{tabular}

\begin{tabular}{|c|c|c|}
\hline $\begin{array}{l}\text { Perfumes }(N=84) \\
\text { Less than RM100 } \\
\text { RM101-RM150 } \\
\text { More than RM150 }\end{array}$ & $\begin{array}{l}64 \\
8 \\
12\end{array}$ & $\begin{array}{l}76.2 \\
9.5 \\
14.3\end{array}$ \\
\hline $\begin{array}{l}\text { Jewelries and accessories }(N=75) \\
\text { Less than RM100 } \\
\text { RM101-RM150 } \\
\text { More than RM150 }\end{array}$ & $\begin{array}{l}50 \\
15 \\
10\end{array}$ & $\begin{array}{l}66.7 \\
20.0 \\
13.3\end{array}$ \\
\hline $\begin{array}{l}\text { Others }(N=145) \\
\text { Less than RM100 } \\
\text { RM101-RM150 } \\
\text { More than RM150 }\end{array}$ & $\begin{array}{l}91 \\
46 \\
8\end{array}$ & $\begin{array}{l}62.8 \\
31.7 \\
5.5\end{array}$ \\
\hline $\begin{array}{l}\text { Average spending per visit }(N=375) \\
\text { Less than RM100 } \\
\text { RM100-RM200 } \\
\text { RM200-RM300 } \\
\text { More than RM300 }\end{array}$ & $\begin{array}{l}22 \\
86 \\
96 \\
171\end{array}$ & $\begin{array}{l}5.9 \\
22.9 \\
25.6 \\
45.6\end{array}$ \\
\hline
\end{tabular}

On average, most of the domestic tourists are found to spend more than RM300 per visit to Padang Besar. Domestic tourists tend to spend mainly on food and beverages. About $54.7 \%$ of 362 of the respondents spent less than RM50 on food and beverages. Besides, tourists spent RM101-RM150 on clothes and less than RM100 on shoes/handbags. For the rest of the items, like household items, cosmetics and beauty products, toys, perfumes, and jewelries and accessories showed that tourists spend less than RM100 while they bought the products. Around 145 tourists also spent on other items. 


\section{The relationship between market characteristics with cross border shopping activities}

There is a significant correlation between market characteristics and cross border shopping which significant value equal to 0.00 less than 0.01 (sig. value $=0.00<0.01$ ). The result shows that all of the factors in market characteristics showed the value less than 0.01 . This is further supported by the positive coefficient of correlation value. The highest positive coefficient is physical factor and other factors $\left(r=0.765^{* *}\right)$ continued by product and service attributes $\left(r=0.708^{* *}\right)$, and shopping area and related attributes showed positive value of $0.699^{* *}$.

Therefore, market characteristics showed strong positive correlation to cross border shopping activities. Three main factors in the market characteristics strongly motivate shoppers to travel to border town. Table below reveals information on border shopping activities. Border shopping activities had strong relationship with market characteristics ( $p$-value $=0.000, r=0$. $\left.803^{\star *}\right)$. The Correlation Coefficient shows the excellent relationship between the variables.

\section{Table 4: Relationship between market characteristics with cross border shopping activities.}

Market Characteristics $\quad$ Correlation $.803^{* *}$

Coefficient $\quad .000$

Sig. (2-tailed)

${ }^{* *}$ Correlation is significant at the 0.01 level (2-tailed).

Table 4 shows there is a significant correlation between market characteristics and cross border shopping. All of the factors in market characteristics like product and service attributes, shopping area and related attributes, physical factor, and other factors show the significant value of 0.000 . The finding is further supported by the positive coefficient of correlation value which is less than 0.01 . Therefore, cross border shopping activities had strong relationship with market characteristics ( $p$ value $\left.=0.000, r=0.803^{\star *}\right)$. The Correlation Coefficient shows the excellent relationship between the variables.

\section{Conclusion}

There are a few studies on cross border shopping throughout the world, but limited studies are found in Malaysia and most of them only focused on retailer, trading rather than on discovering the motivation, behavior, and personal characteristics of cross border shoppers who purchase at the border town. In this study, the review is on the domestic tourist profiles, their spending patterns, border movement, and the factors motivating the tourists to travel. The relationship between the variables is discovered.

As a result, the product and service attributes, shopping area and related attributes, and physical factors are the factors perceived by the respondents, thus noting that the major factor that influenced shopping activities is product and merchandise offered in that place. This statement is also supported by other researchers who observed the range of prices as the factor that makes shopping activities as a pleasurable experience ${ }^{[20]}$.

\section{References}

[1] Timothy, D. J. (2005). Aspects of tourism, shopping tourism, retailing and leisure. Channel View Publications.

[2] Azmi, A., Hamid, I., A., Ahmad, J., A., \& Ramli, R. A. (2016). Tourism supply chain perspectives on border shopping development at Padang Besar, Malaysia in balancing development and sustainability in tourism destinations. Springer.

[3] Subramaniam, T., Devadason, E., \& Sundararaja, S. (2008). Cross-border shopping behaviour of Bruneians in Limbang, Sarawak: A preliminary analysis. Borneo Research Journal, 2.

[4] Azmi, A., Sapi, M. E. A., \& Rahman, S. M. S. A. (2015). Factors influencing cross-border shopping. ESTEEM Academic Journal, 11(2), 27-34.

[5] Ibrahim, J. A. \& Ahmad, M. Z. (2010). Cross-border tourism: Potential and challenges. 2, 260-272. 
[6] Azmi, A., Ngelambong, A., Anuar, J., \& Lahap, J. (2015). Border shopping activities, facilities and development in Padang Besar, Perlis. Hospitality and Tourism 2015: Proceedings of HTC 2015 (Malacca, Malaysia, 2-3 November 2015), 361.

[7] Azmi, A., Sulaiman, S., Asri, D. A. M., \& Razali, M. A. (2015). Shopping tourism and trading activities at the border town of Malaysia-Thailand: A case study in Padang Besar. International Academic Research Journal of Social Science, 1(2), 2015, 83-88.

[8] Barter, P. A. (2006). Multiple dimension in negotiating the cross-border transport links that connects and divide Singapore and Johor, Malaysia. 47(2), 287-303

[9] Bakar, N. R. A., Abdullah, M. Y., \& Awang, A. H. (2012). Kesejahteraan bersama melalui hubungan dagangan dan sosial di sempadan Kalimantan Barat dan Serikin, Sarawak. 8(8), 91-95.

[10] Anaman, K. A., \& Ismail, R. A. (2002). Cross-border tourism from Brunei Darussalam to eastern Malaysia: An empirical analysis. The Singapore Economic Review, 47(1), 65-87.

[11] Kitchenham, B., \& Pfleeger, S. (2002). Principles of survey research part 2: Designing a survey. ACM SIGSOFT Software Engineering Notes, 27(1), 18-20.

[12] Clark, T. (1994). National boundaries, border zones, and marketing strategy: A conceptual framework and theoretical model of secondary boundary effects. Journal of Marketing, 58, 67-80.

[13] Lau, H., Sin, L., \& Chan, K. (2005). Chinese cross-border shopping: An empirical study. Journal of Hospitality and Tourism Research, 29(1), 110-133

[14] Piron, F. (2002). International outshopping and ethnocentrism. European Journal of Marketing, 36(1/2), 189210.

[15] Beck, R. (1998, July 30). Forget the beach, travelers' option for the mall on vacations. Sentinel Tribute (Bowling Green).

[16] Jansen-Verbeke, M. (1991). Leisure shopping: A magic concept for the tourism industry. Tourism Management, $12,9-14$

[17] Timothy, D. J., \& Butler, R. W. (1995). Cross-border shopping: A North American perspective. Annals of Tourism, 22(1), 16-95.

[18] McCormick, R. R. (2001). Shopping. Paper presented at the Travel Industry Association of America Marketing Outlook Forum.

[19] Travel Industry Association of America. (2001). The shopping traveler. Washington, DC.

[20] Howard, E. (2007). New shopping centres: Is leisure the answer? International Journal of Retail and Distribution Management, 35(8), 661-672. 